\title{
Terminus behavior and response time of North Cascade glaciers, Washington, U.S.A.
}

\author{
Mauri S. Pelto, ${ }^{1}$ Clifff Hedlund ${ }^{2}$ \\ ${ }^{1}$ Department of Environmental Science, Nichols College, Dudley, Massachusetts 01571, U.S.A. \\ ${ }^{2}$ Department of Geosciences, Oregon State University, Corvallis, Oregon 97331, U.S.A.
}

\begin{abstract}
Observation of the terminus behavior of 38 North Cascade glaciers, Washington, U.S.A., since 1890 shows three different types of glacier response: (1) Continuous retreat from the Little Ice Age (LIA) advanced positions from 1890 to approximately 1950, followed by a period of advance from 1950 to 1976, and then retreat since 1976. (2) Rapid retreat from 1890 to approximately 1950, slow retreat or equilibrium from 1950 to 1976, and moderate to rapid retreat since 1976. (3) Continuous retreat from 1890 to the present.

Type 1 glaciers are notable for steeper slopes, extensive crevassing and higher terminusregion velocities. Type 2 glaciers have intermediate velocities, moderate crevassing and intermediate slopes. Type 3 glaciers have low slopes, modest crevassing and low terminusregion velocities. This indicates that the observed differences in the response time and terminus behavior of North Cascade glaciers in reaction to climate change are related to variations in specific characteristics of the glaciers. The response time is approximately $20-30$ years on type 1 glaciers, 40-60 years on type 2 glaciers and a minimum of 60-100 years on type 3 glaciers. The high correlation in annual balance between North Cascade glaciers indicates that microclimates are not the key to differences in behavior. Instead it is the physical characteristics - slope, terminus velocity, thickness and accumulation rate - of the glacier that determine recent terminus behavior and response time. The delay between the onset of a mass-balance change and initiation of a noticeable change in terminus behavior has been observed on 21 glaciers to be $4-16$ years. This initial response time applies to both positive and negative changes in mass balance.
\end{abstract}

\section{INTRODUCTION}

Observation of the different terminus behaviors of North Cascade glaciers, Washington, U.S.A., in response to climate changes during the last century (Tangborn and others, 1990) has prompted the evaluation of the terminus behavior of 38 of these glaciers for the 1890s-1990s period. The objective is to determine the characteristics that lead to the differential terminus behavior.

To complete this task requires examination of the response time of glaciers to climate change. For any glacier there is a lag time $\left(T_{\mathrm{S}}\right)$, or reaction time, between a significant climate change and the initial observed terminus response (Paterson, 1994). It should be noted that $T_{\mathrm{S}}$ cannot be considered a physical property of a glacier and is expected to depend on the mass-balance history and physical characteristics of the glacier. In this paper, $T_{\mathrm{S}}$ is simply defined as the time lag from an observed climate shift to the initial observed change from an advancing to a retreating, or from a retreating to an advancing, terminus.

In addition, for each glacier there is a response time, the time taken to approach a new steady state for a given climatedriven mass-balance change $\left(T_{\mathrm{m}}\right)$, referred to as length of memory by Jóhannesson and others (1989). Jóhannesson and others (1989) defined $T_{\mathrm{m}}$ as the time-scale for exponential asymptotic approach to a final steady state (approximately $63 \%$ of a full response), resulting from a sudden change in climate to a new constant climate. The magnitudes of $T_{\mathrm{s}}$ and $T_{\mathrm{m}}$ are crucial for interpreting past and current glacier fluctuations and predicting future changes (Jóhannesson and others, 1989; Paterson, 1994).

In nature a step change in climate causing an evolution from an initial to a final steady state never occurs (Schwitter and Raymond, 1993). The variability of climate forcing and the continuous changes in the glacier superimpose new disturbances on the response of the glaciers to previous climate changes. This leads to the conclusion that $T_{\mathrm{m}}$ cannot be defined directly from observations in nature. However, $T_{\mathrm{m}}$ cannot be accurately defined from models alone either.

In this study we recognize that the terminus response is influenced by ongoing changes in forcing, limiting the accuracy of determination of $T_{\mathrm{m}}$ from terminus observations. Rather than attempt direct calculation of $T_{\mathrm{m}}$ from terminus observations, we use observations to establish limits on the range of $T_{\mathrm{m}}$. Our estimates are based on the understanding that, during a period of relatively constant climate, the glacier should advance/retreat to about two-thirds of the final adjustment in its terminus positions, and the rate of advance/retreat of the terminus should be reduced to approximately one-third over a time period of length $T_{\mathrm{m}}$. The difficulty of examining terminus response to a specific step change is minimized with respect to the post-Little Ice Age (post-LIA) warming, because the climate change and associated terminus response is large compared to climate changes and resulting terminus changes that have occurred in the last half-century (Burbank, 1981; Porter, 1986; Schwitter and Raymond, 1993).

In the North Cascades the disparate terminus behavior 
of glaciers has been noted by Hubley (1956), Post and others (1971), Tangborn and others (1990) and Pelto (1993). The primary goal of this paper is to examine the observed terminus behavior and glacier geographic characteristics of 38 North Cascade glaciers to determine why the terminus behavior history varies. The secondary goal is to identify the ranges of $T_{\mathrm{s}}$ and $T_{\mathrm{m}}$ for the response of North Cascade glaciers to climate changes.

\section{DATA USED}

The North Cascade Glacier Climate Project (NCGCP) has been observing terminus behavior on 47 North Cascade glaciers and measuring annual balance on 9 glaciers since 1984 (Pelto, 1993, 1996). The primary objective of this research has been to identify the magnitude and timing of glacier response to climate change. This NGGCP dataset is extensive in its breadth, but not in its length of record. Extensive U.S. Geological Survey (USGS) aerial photographic collections and ongoing research by the USGS on South Cascade Glacier have been indispensable to this research, providing long-term records.

\section{Terminus observations}

The magnitude of terminus changes from the Little Ice Age Maximum (LIAM) has been measured on 38 glaciers by utilizing 720 USGS vertical aerial photographs taken by A. Post between 1962 and 1979, 150 aerial photographs taken by R. C. Hubley of the University of Washington from 1950 to 1955, and 120 photographs taken by J. B. Richardson and W. Long of the U.S. National Forest Service from 1940 to 1960 (all of these photographs have been donated to NCGCP by W. Long, A. Post and the USGS).

Schwitter and Raymond (1993) noted the ease of identification and utility of the well-preserved LIA moraines for reconstructing former glacier profiles in the North Cascades and elsewhere. The distance from the typically wellpreserved, fresh LIA moraines and trimlines to the current glacier front has been measured from USGS vertical aerial photographs. Additionally, on each of the 38 glaciers field measurements from the same LIA moraines to the current glacier front were completed on at least two occasions between 1984 and 1998 using a laser ranging device $( \pm 1 \mathrm{~m})$, the goal being to verify both the LIAM and the actual terminus position changes from 1984 to 1998. In two cases the field measurements and photographic measurements differed by $>20 \mathrm{~m}$; these glaciers are therefore not used in this analysis.

The 1850-1950 terminus change is the distance from the LIAM to the position of the glacier terminus in 1950 as noted by Hubley (1956). The 1950-79 terminus change is the change between the position noted by Hubley (1956) and the USGS aerial observations in 1979. Neither 1950 nor 1979 perfectly matches the timing of climate changes noted in the following section, but they come closest to the climate shifts, beginning in 1944 and 1976, respectively, for which adequate aerial photographic observations were made. Terminus change from 1979 to the present is based on comparison of the USGS aerial observations and repeated NCGCP field measurements from 1984 to 1998 (Pelto, 1993, 1996).

To determine $T_{\mathrm{s}}$ a group of 21 North Cascade glaciers was observed that switched from retreat to advance shortly after 1944, and from advance to retreat shortly after 1976. The initial post-1944 glacier advances were observed by Long
Table 1. Number of terminus observations used in this study for each of the 17 glaciers where $T_{\mathrm{m}}$ has been both derived from field observations and calculated from theoretical equations, and the interval of mass-balance and velocity observations at the terminus of each glacier ( $b_{\mathrm{t}}$ and $u_{\mathrm{t}}$, respectively)

\begin{tabular}{|c|c|c|c|c|c|c|}
\hline \multirow[b]{2}{*}{ Glacier } & \multirow[b]{2}{*}{$1950-55$} & \multicolumn{3}{|c|}{ Number of observations } & \multirow[b]{2}{*}{ 1984-98 } & \multirow[b]{2}{*}{$b_{\mathrm{t}}$ and $u$} \\
\hline & & $1964-67$ & $1970-72$ & 1979 & & \\
\hline Colonial & 2 & 1 & 2 & 1 & 5 & 1992-96 \\
\hline Columbia & 2 & 1 & 2 & 1 & 15 & 1984-98 \\
\hline Daniels & 3 & 1 & 2 & 1 & 15 & 1984-98 \\
\hline Easton & 4 & 2 & 2 & 1 & 7 & $1991-96$ \\
\hline Foss & 2 & 1 & 2 & 1 & 15 & 1984-98 \\
\hline Honeycomb & 3 & 2 & 2 & 1 & 3 & 1994-96 \\
\hline Ice Worm & 3 & 1 & 2 & 1 & 15 & 1984-98 \\
\hline Kennedy & 3 & 2 & 2 & 1 & 4 & 1994-96 \\
\hline Ladder Creek & 2 & 1 & 2 & 1 & 4 & $1992-96$ \\
\hline Lewis & 2 & 1 & 2 & 1 & 15 & 1984-89 \\
\hline Lower Curtis & 3 & 1 & 2 & 1 & 15 & 1984-98 \\
\hline Lyman & 3 & 1 & 2 & 1 & 6 & 1994-96 \\
\hline Lynch & 3 & 1 & 2 & 1 & 15 & 1984-98 \\
\hline Neve & 2 & 1 & 2 & 1 & 4 & 1992-96 \\
\hline Rainbow & 2 & 1 & 2 & 1 & 15 & 1984-98 \\
\hline South Cascade & 4 & 4 & 3 & 1 & 15 & 1958-98 \\
\hline Yawning & 2 & 1 & 2 & 1 & 15 & 1984-98 \\
\hline
\end{tabular}

(1955, 1956) and Hubley (1956). Observations of the onset of retreat after 1976 are from Heikinnen (1984), NCGCP field observations (Pelto, 1993) and USGS aerial photographs from 1979.

\section{Glacier characteristics}

On 17 of the aforementioned 38 glaciers more detailed observations are used to calculate theoretical estimates of $T_{\mathrm{m}}$ for comparison with observations of terminus behavior. Each of these 17 glaciers had at least five terminus observations during the period 1850-1998 (Table 1) (Long, 1955; Hubley, 1956; Meier and Post, 1962; Post and others, 1971; Pelto, 1993). In order to calculate $T_{\mathrm{m}}$, terminus velocity $u_{\mathrm{t}}$, mass balance near the terminus $b_{\mathrm{t}}$, ice thickness $h$ and glacier length $l$ must be determined. Annual balance measurements have been performed on 9 of the 17 glaciers over a span of $>10$ years (Table 1) (Krimmel, 1996; Pelto, 1996). Krimmel (1999) has observed $b_{\mathrm{t}}$ and $u_{\mathrm{t}}$ on South Cascade Glacier. On the other 16 glaciers $b_{\mathrm{t}}$ and $u_{\mathrm{t}}$ have been directly observed for at least two hydrologic years using stakes drilled into the glacier terminus area by NCGCP (Pelto, 1996; Krimmel, 1999). Measurement of $u_{\mathrm{t}}$ relied on at least three points, in the lower $25 \%$ of the glacier's length, which is within $200 \mathrm{~m}$ of the terminus in each case. The longer-term annual balance measured on nine of these glaciers indicates that the period of record for terminus mass-balance measurement (1994-96) was close to the 1984-97 mean.

Krimmel (1999) observed the length of South Cascade Glacier in 1998. The length of the other 16 glaciers has been taken from the most recent USGS maps compiled from aerial photographs between 1982 and 1984, and adjusted for the observed retreat up to 1998.

Glacier thickness $h$ has been measured on three North Cascade glaciers, namely, South Cascade Glacier (Krimmel, 1970), Easton Glacier (Harper, 1993) and Lewis Glacier. The first two are comparatively large glaciers, each with a maximum mean profile depth of 60-80 m. These measurements and those of Driedger and Kennard (1986) on Cascade vol- 


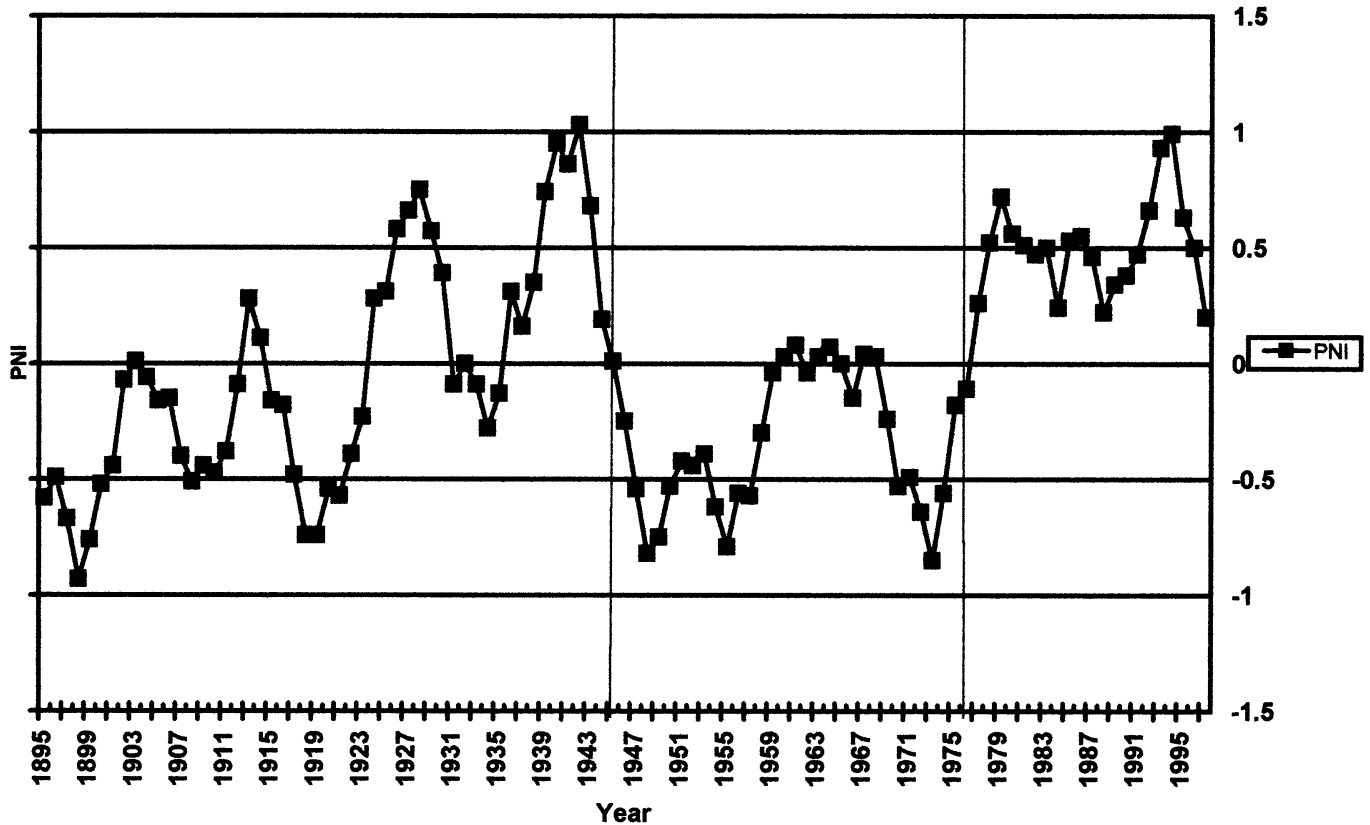

Fig. 1. Five-year running mean of PNI, 1985-1997 (Ebbesmeyer and others, 1990). Note the increasingly high values from 1895 to 1944, low values from 1945 to 1976 and high values from 1977 to 1997.

canoes, which yielded a mean thickness of $50 \mathrm{~m}$ on Mount Rainier and $35 \mathrm{~m}$ on Mount Hood, show that these glaciers are comparatively thin. On Lewis Glacier the thickness was measured in a moulin that reached the base of the glacier in 1985, 1986 and 1987. The thickness of each of the other 14 glaciers, where direct measurements were not made, is assumed to be $50 \mathrm{~m}$ on thin concave or slope glaciers and $100 \mathrm{~m}$ on thicker convex or valley glaciers. In both cases the resulting $h$ is a maximum value, so the $T_{\mathrm{m}}$ also would be a maximum value (Post and others, 1971).

\section{Climate data}

A good single climate indicator for North Cascade glacier behavior is the Pacific Northwest Index (PNI), developed by Ebbesmeyer and others (1991). Figure 1 plots the PNI during the period 1896-1997. The index is based on 15 March snowpack depth at Paradise on Mount Rainier, mean annual temperature at Olga and total annual precipitation at Cedar Lake (all sites in Washington). Positive values reflect negative glacier mass balances.

\section{TERMINUS OBSERVATIONS}

Since the maximum advance of the LIA there have been three climate changes in the North Cascades sufficient to substantially alter glacier terminus behavior. During the LIA, mean annual temperatures were $1.0-1.5^{\circ} \mathrm{C}$ cooler than at present (Burbank, 1981: Porter, 1986). The lower temperatures in the North Cascades led to a snowline lowering of 100-150 $\mathrm{m}$ during the LIA (Burbank, 1981; Porter, 1986). Depending on the glacier, the maximum advance occurred in the 16th, 18th or 19th century (Long, 1956; Miller, 1969). North Cascade glaciers maintained advanced terminal positions from 1650 to 1890 , emplacing one or several LIA terminal moraines.

Retreat from the LIAM was modest prior to a stillstand in the 1880s (Long, 1956; Burbank, 1981). Miller (1969) mapped the age of terminal moraines in front of Chickamin and South Cascade Glaciers and found in each case that a late-19thcentury moraine was emplaced within $100 \mathrm{~m}$ of the LIAM.
Just south of the study area, mapping of terminus changes by Burbank (1981) indicates that rapid and continuous retreat of Mount Rainier glaciers from their LIAM began after the 1880-85 stillstand. Long (1953) noted that retreat on Lyman and Easton Glaciers became substantial only after 1890. Long (1955) noted that Lyman Glacier has been retreating steadily since the 1890s. Climate warming and retreat began about 1850, but because of the modest retreat and subsequent stillstand or advance of North Cascade glaciers around 1880, 1890 is taken as the approximate time for the climate change that initiated a continuous substantial retreat from the LIA advanced positions in the North Cascades.

This first substantial climate change was a progressive temperature rise from the 1880 s to the 1940 s, which led to ubiquitous rapid retreat of North Cascade Range alpine glaciers from 1890 to 1944 (Rusk, 1924; Long, 1955; Hubley, 1956; Burbank, 1981). Each North Cascade glacier retreated significantly from its LIAM. The retreat did not occur exclusively in the 1890-1944 time period; observations do not exist on most glaciers to distinguish the exact timing of the initial post-LIAM retreat, though retreat was minor before 1890 on glaciers where observations exist. The average retreat of glaciers on Mount Baker was $1440 \mathrm{~m}$ from the LIAM to 1950 (Pelto, 1993). The average retreat of the 38 North Cascade glaciers in this study was $1215 \mathrm{~m}$.

The 1895-1923 PNI is rising, but has a comparatively low mean $(-0.34)$ that is still capable of generating retreat on North Cascade glaciers that remain in advanced positions from the LIA. The 1924-44 PNI average was high at 0.44 . This warm, dry period was one of rapid glacier retreat worldwide (Long, 1955; Hubley, 1956; Burbank, 1981). The second substantial change in climate began in 1944, when conditions became cooler and precipitation increased (Hubley, 1956; Tangborn, 1980). The climate change in 1944 is evident in the PNI record (Fig. 1). The 1945-76 mean PNI was -0.37 . This drop of 0.76 in the PNI average compared to the previous time period marks the climate change that initiated the advance of some North Cascade glaciers and the more positive mass balance for that period (Hubley, 1956; Tangborn, 1980).

Hubley (1956) and Long (1956) noted that North Cas- 
cade glaciers began to advance in the early 1950s, after 30 years of rapid retreat. This change was reflected in mass-balance values. A runoff-precipitation model constructed for South Cascade Glacier (Tangborn, 1980) yielded a mean annual balance of $-1.15 \mathrm{~m} \mathrm{a}^{-1}$ from 1924 to 1944, compared to $-0.15 \mathrm{~m} \mathrm{a}^{-1}$ from 1945 to 1976.

Approximately half the North Cascade glaciers advanced during the period 1950-79 (Hubley, 1956; Meier and Post, 1962). Advances of Mount Baker glaciers ranged from 120 to $750 \mathrm{~m}$, an average of $480 \mathrm{~m}$, and ended in 1978 (Heikkinen, 1984; Harper, 1993; Pelto, 1993). All 11 Glacier Peak glaciers that advanced during the period 1950-79 emplaced an identifiable maximum advance terminal moraine; the mean advance was $295 \mathrm{~m}$. Of the 47 glaciers observed by NCGCP during the period 1984-98, 15 advanced during the period 1950-78.

The final climate change was a step change in 1977 to a drier, warmer climate in the Pacific Northwest (Ebbesmeyer and others, 1991). The mean PNI for 1977-98 was 0.53, even higher for 1924-44, indicating a warmer, drier period that re-established the ubiquitous retreat of North Cascade glaciers (Pelto, 1993). This change impacted glacier mass balance, alpine stream-flow and alpine snowpack (Ebbesmeyer and others, 1991). The impact on North Cascade glacier mass balance is evident from the USGS long-term record of South Cascade Glacier (1958-98), where mean annual balance was $-0.15 \mathrm{~m} \mathrm{a}^{-1}$ for the period $1958-76$, in contrast to $-1.00 \mathrm{~m} \mathrm{a}^{-1}$ for the period 1977-98 (Krimmel, 1999).

The retreat and negative mass balances of the 1977-98 period have been noted by Harper (1993), Pelto (1993, 1996) and Krimmel (1994, 1999). By 1984, all the Mount Baker glaciers, which were advancing in 1975, were again retreating (Pelto, 1993). In 1997-98, NCGCP measured the retreat of eight Mount Baker glaciers from their recent maximum position (late 1970s-early 1980s). The average retreat had been $-197 \mathrm{~m}$. Photographs from J. B. Richardson and observations by A. Post (personal communication, 2000) show that all of the Mount Baker termini are still in advance of their 1940 position. However, the glacier region between the current terminus and 1940 terminus is nearly stagnant on each of the glaciers. Between 1979 and 1984, 35 of the 47 North Cascade glaciers observed annually by NCGCP had begun retreating. By 1992 all 47 glacier termini observed by NCGCP were retreating (Pelto, 1993) and two, Lewis and Milk Lake Glaciers, had disappeared.

\section{INITIAL TERMINUS RESPONSE}

The time between the onset of a mass-balance change and the onset of a significant change in terminus behavior is called the initial terminus response time or reaction time $\left(T_{\mathrm{s}}\right)$. As indicated previously, $T_{\mathrm{S}}$ is a descriptive quantity that quantifies the time lag between climate forcing and terminus response for a particular climate event, rather than a physical property of a glacier. $T_{\mathrm{S}}$ in this study is based solely on the first observed terminus change from retreat to advance after 1944, and from advance to retreat after 1976. $T_{\mathrm{S}}$ has been identified from the response of North Cascade glaciers to the cooler, wetter weather beginning in 1944 (Long 1955, 1956; Hubley, 1956; Tangborn, 1980), and to the subsequent warmer, drier conditions beginning in 1977 (Pelto, 1988, 1993; Ebbesmeyer and others, 1991; Harper, 1993; Krimmel, 1994).

Focusing on 21 North Cascade glaciers that responded to
Table 2. Date of first observed advance following the 1944 climate change, and of first observed retreat following the climate change in 1976/77

\begin{tabular}{lcc}
\hline Glacier & Advance observed & Retreat observed \\
\hline Coleman & 1949 & 1979 \\
Easton & 1960 & 1989 \\
Deming & 1955 & 1986 \\
Boulder & 1954 & 1985 \\
Squak & 1955 & 1985 \\
Rainbow & 1955 & 1985 \\
Kennedy & 1955 & 1986 \\
Chocolate & 1950 & 1986 \\
North Guardian & 1955 & 1986 \\
Dusty & 1955 & 1986 \\
Ptarmigan & 1960 & 1988 \\
Vista & 1960 & 1988 \\
Ermine & 1955 & 1986 \\
Ladder Creek & 1955 & 1987 \\
Eldorado & 1955 & 1984 \\
Quien Sabe & 1955 & 1984 \\
Yawning & 1955 & 1986 \\
Lower Curtis & 1955 & 1987 \\
Challenger & 1955 & 1985 \\
Price & 1954 & 1987 \\
Chimney Rock & 1955 & 1987 \\
\hline
\end{tabular}

these two climate shifts, all having an area of $<10 \mathrm{~km}^{2}$, the initial terminus response invariably is <16 years (Hubley, 1956; Harper, 1993; Pelto, 1993). Table 2 lists 21 North Cascade glaciers where $T_{\mathrm{S}}$ has been noted for both advance and retreat in the post-1944 period by Long $(1955,1956)$ or Hubley (1956). In each case the glaciers were observed to be in retreat during the 1940s, and subsequently advanced within 16 years of the climate change. Table 2 also notes the response of the same glaciers from a period of advance by each glacier in the early 1970 s to one of retreat by 1988, 12 years after the climate change (Pelto, 1988, 1993; Harper, 1993). The observed $T_{\mathrm{s}}$ is not significantly different on individual glaciers for initiation of advance vs initiation of retreat.

Many North Cascade glaciers did not respond to these two climatic changes. This may be due to a longer $T_{\mathrm{S}}$, or more likely is due to either an ongoing retreat caused by continuing negative mass balances, or the fact that climate change was insufficient to substantially alter mass balance on these glaciers.

\section{ANALYSIS AND GLASSIFICATION OF GLAGIER RESPONSE}

The 38 North Cascade glaciers where the terminus history has been determined for the period 1890-1998 exhibit three distinct patterns (Table 3): (1) Retreat from 1890 to 1950, then a period of advance from 1950 to 1976, followed by retreat since 1976. (2) Rapid retreat from 1890 to approximately 1950, slow retreat or equilibrium from 1950 to 1976 and moderate to rapid retreat since 1976. (3) Continuous retreat from 1890 to the present. Assignment of a glacier's type is based solely on its terminus behavior in this analysis.

\section{Type 1 glaciers}

From 1890 to 1946 a retreat of at least $1000 \mathrm{~m}$ occurred on each of the significant glaciers $\left(>1.0 \mathrm{~km}^{2}\right)$ on Mount Baker and Glacier Peak: Mazama, Rainbow, Easton, Squak, Talum and Boulder Glaciers on Mount Baker, and Ermine, Dusty, 
Table 3. Retreat of North Cascade glaciers for three intervals since the LIAM. The mean slope of the glacier surface, the mean altitude of the glacier and the surface area of the glacier are also listed

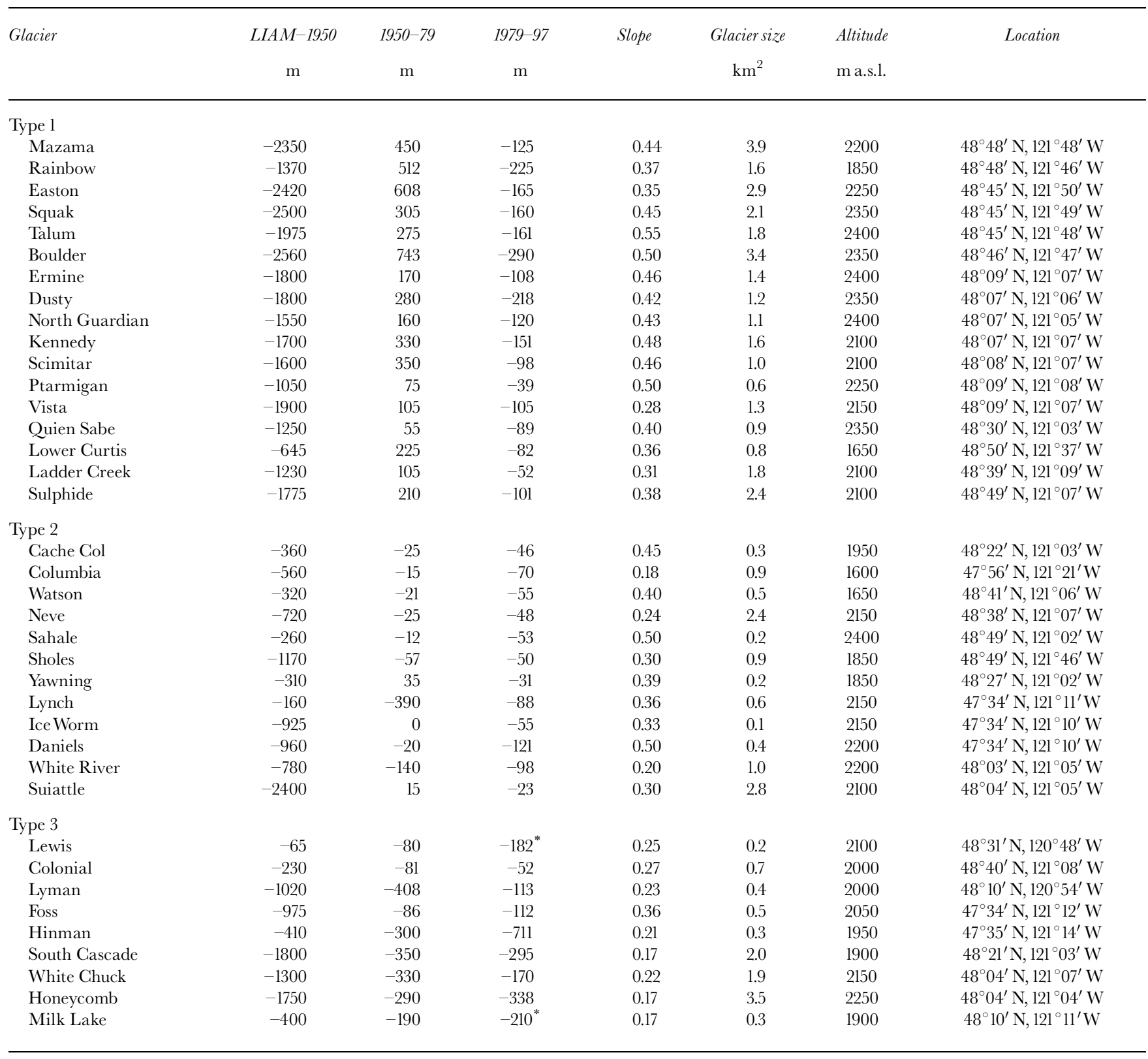

${ }^{*}$ The retreat ended with the loss of the glacier.

North Guardian, Kennedy, Scimitar, Ptarmigan and Vista Glaciers on Glacier Peak are used in this study; each of these is a type 1 glacier. The two strato-volcanoes, Glacier Peak and Mount Baker, are the highest peaks in the North Cascades. The ability to advance was not limited to the high-elevation glaciers of the two large volcanoes, as this advance was also noted on other North Cascade glaciers: Ladder Creek, Challenger, Quien Sabe, Lower Curtis, Sulphide and North Klawatti Glaciers (Hubley, 1956).

Even in 1940, at the height of retreat, type 1 glaciers were extensively crevassed and quite active in the photographs taken by W. Long and J. B. Richardson. Today, despite moderate to rapid retreat rates of $10-30 \mathrm{~m} \mathrm{a}^{-1}$, all type 1 glaciers remain extensively crevassed.

Each type 1 glacier was still retreating appreciably in 1940 but had come close enough to equilibrium that the climate shift beginning in 1944, indicated by a decrease of the mean PNI of approximately 1 , brought about a rapid change from retreating to advancing conditions (Hubley, 1956). The 50 years of continuous retreat reflects type 1 glacier response to the initial climate shift in approximately 1890, the progressive warming during the 1895-1923 period and the warmth of the 1924-44 period (Long, 1955; Burbank, 1981). While none of the glaciers had achieved a full adjustment by 1940, they appeared to be approaching it, suggesting that $T_{\mathrm{m}}$ is in the 20-30 year range for type 1 glaciers.

Similarly, by 1976, advance had brought these glaciers close enough to equilibrium, as evidenced by the slow rate of terminus change (Harper, 1993), that the modest (10\%) recent decline in winter precipitation and rise in summer temperature $\left(1.1^{\circ} \mathrm{G}\right.$ ) resulted in glacier retreat (Harper, 1993; Pelto, 1993, 1996). This again indicates that $T_{\mathrm{m}}$ is in the range $20-30$ years. It must be acknowledged that these glaciers became smaller after the post-LIA warming, so $T_{\mathrm{m}}$ should be shorter.

\section{Type 2 glaciers}

Each of these glaciers retreated substantially from 1890 to 1950, followed by nearly stable terminus positions between 1955 and 1979, and an increasing retreat rate since 1984. 
Type 2 glaciers in this study are Columbia, Watson, Cache Col, Yawning, Sahale, Neve, Ice Worm and Suiattle Glaciers. The maximum retreat or advance of this group was $<30 \mathrm{~m}$ from 1955 to 1984 . Since 1984 the retreat rate has been increasing for this group of glaciers; the average for the 199298 period was $8 \mathrm{ma}^{-1}$. In 1998 the retreat rate remained modest as the glaciers still appeared to be adjusting slowly to climate change.

An increase in crevassing was noted on Neve, Yawning and Suiattle Glaciers in 1955, but little or no advance occurred, though the retreat ended in the early 1970s on these three glaciers. This suggests that the climate change was insufficient to generate an advance, but did manage to halt the ongoing retreat.

After continuously retreating from 1890 to 1950, the type 2 glaciers had not come close enough to equilibrium for the 1944 climate shift to stop the retreat initially. This suggests that $T_{\mathrm{m}}$ for type 2 glaciers is on the order of $40-60$ years, since each glacier terminus was close to equilibrium after the 1944 climate change but had not yet attained equilibrium due to the 1890 climate change. Exponential filtering of the PNI also indicates that a response time in this range is required to approximately halt the retreat in the period 1944-76 (personal communication from T. Jóhannesson, 2000).

\section{Type 3 glaciers}

This group includes South Cascade, Honeycomb, Foss, Hinman, Milk Lake, Lyman, Whitechuck, White River, Lewis, Sholes and Colonial Glaciers. Each of these retreated continuously throughout the 20th century. The most rapid retreat period has varied, but each glacier retreated $>100 \mathrm{~m}$ between 1950 and 1979 and thinned appreciably while many North Cascade glaciers were advancing or in equilibrium (Hubley, 1956; Meier and Post, 1962).

Type 3 glaciers have a low slope, limited crevassing and generally low velocities for their size. South Cascade Glacier is a good example. Lyman, Hinman, Foss and Colonial Glaciers have each lost $>50 \%$ of their area in the last 50 years. Of these four only Lyman Glacier is still moving at a detectable rate; the other three had continuously negative mass balances and will disappear in the current climate. None of the type 3 glaciers has neared a post-LIA equilibrium.

The disappearance of two glaciers in this group, Lewis Glacier in 1989 and Milk Lake Glacier in 1993, shows that after nearly 150 years of adjustment these glaciers had failed to achieve a new equilibrium. That none of the glaciers had achieved equilibrium by 1975, after 85 years of retreat, indicates a $T_{\mathrm{m}}$ of at least $60-100$ years for type 3 glaciers. The complete melting away of Hinman and Foss Glaciers may take another 50 years despite their small size.

South Cascade Glacier is the most studied glacier in the North Cascades. The USGS has monitored the mass balance since 1952. The mass-balance trend through time indicates that the $1958-76$ mean annual balance was $-0.15 \mathrm{ma}^{-1}$ (Krimmel, 1999). The 1945-75 period of more positive mass balance, which generated advance for many North Cascade glaciers, resulted in smaller negative balances but a significant ongoing retreat (Krimmel, 1996). The 1977-98 mean annual balance on South Cascade Glacier was $-1.0 \mathrm{~m} \mathrm{a}^{-1}$ (Krimmel, 1999), and retreat has been rapid. During the 1940-98 period for which terminus observations exist, South Cascade Glacier has not approached equilibrium.

None of the type 3 glaciers has approached a steady state
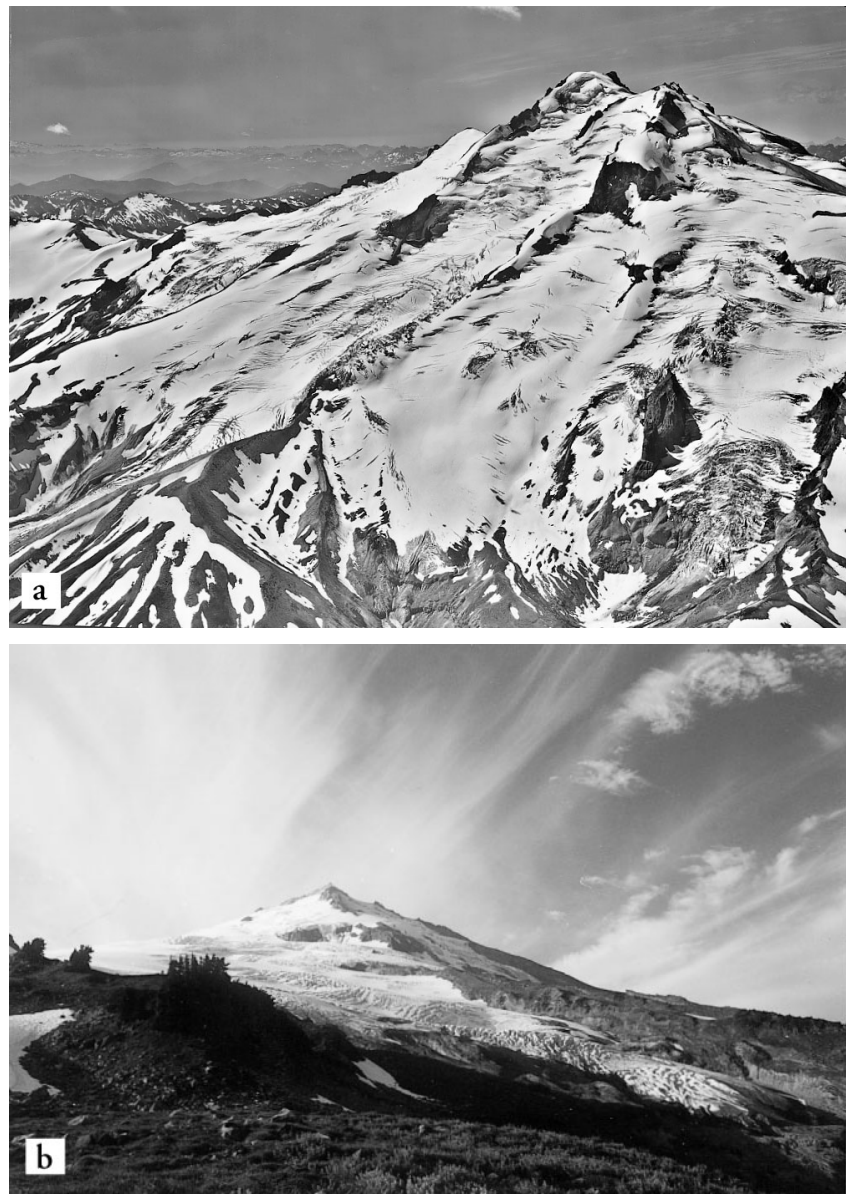

Fig. 2. (a) Glacier Peak in 1972. From right to left, Chocolate to North Guardian and Dusty Glaciers are typical type 1 glaciers, steep, crevassed and with high accumulation rates. The glaciers are just ending a period of advance at the time of this photograph ( A. Post, USGS). (b) Squak Glacier on Mount Baker in 1990.

This longitudinal view of the glacier indicates the consistent degree of crevassing and rapid flow of this type 1 glacier.

since the end of the LIA, regardless of the fluctuations in mass balance and the low values of the proxy forcing function PNI from 1945 to 1976. Type 3 glaciers are still adjusting in part to the post-LIA climate change, which has been reinforced by recent warming. It therefore seems likely that type 3 glaciers and South Cascade Glacier are still adjusting to the post-LIA warming after a century of retreat and that $T_{\mathrm{m}}$ is at least 60-100 years.

\section{GHARAGTERISTICS OF GLACIER TYPES}

Each of the three glacier types was established based solely on terminus behavior history, but it is apparent that each type has specific characteristics (Figs 2-5). Figure 6 illustrates the different terminus behavior histories of North Cascade glaciers. The slower initial response to climate change of type 3 glaciers is evident. The long-term result of the slow start is a more persistent retreat. Table 3 lists the mean slope, mean altitude and area of each of the 38 glaciers. Mass-balance measurements in the accumulation zone exist for 12 of the glaciers in this study. Type 1 glaciers have the highest mean elevations (2200 ma.s.l.), largest mean slope $(0.42 \pm 0.07)$, highest measured mean accumulation (Pelto, 1988, 1996), most extensive crevassing and highest measured terminus-region velocity $\left(20 \pm 3 \mathrm{~m} \mathrm{a}^{-1}\right)$. Type 3 glaciers have the lowest slopes $(0.23 \pm 0.06)$, least cre- 


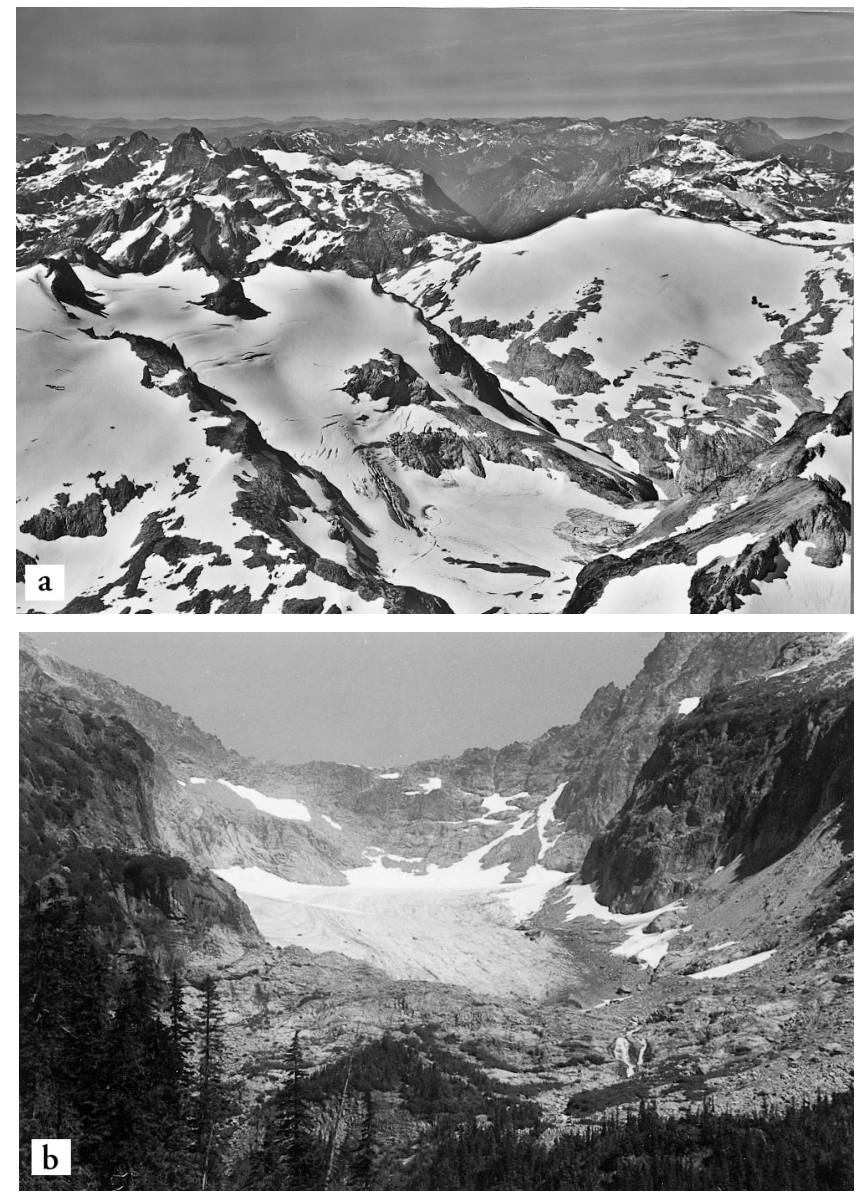

Fig. 3. (a) Lynch Glacier in 1972. A type 2 glacier, it is steep, but with fewer crevasses, and has not stopped retreating during the past century. Foss Glacier on the right is a type 3 glacier with a lower slope and less crevassing (A. Post, USGS). (b) Columbia Glacier in 1986. This type 2 glacier receives particularly large avalanche accumulation.

vassing and lowest mean terminus velocity $\left(5 \pm 3 \mathrm{~m} \mathrm{a}^{-1}\right)$ of any of the glacier types. Type 2 glaciers have on average a lower slope $(0.35 \pm 0.08)$, a lower terminus-region velocity $\left(7 \pm 4 \mathrm{~m} \mathrm{a}^{-1}\right)$, less crevassing and a lower mean accumulation rate than type 1 glaciers (Fig. 3).

There is no significant relation between aspect and glacier type. A larger mean slope, higher accumulation rates, more extensive crevassing and higher velocity either reflect or lead to increased glacier velocities and longitudinal strain rates. The greater the longitudinal strain rate the faster the glacier can adjust to changing climate conditions (Paterson, 1994). The terminus-region velocities on large alpine glaciers may be quite independent of glacier velocity as a whole. On the smaller North Cascade glaciers, the terminus-region velocity is, on the other hand, a good indicator of mean glacier velocity.

The three glacier types show that persistent differences in glacier behavior can be explained in terms of the basic characteristics of the glacier which in turn determine response time, and are not specific to individual glaciers. This is reinforced by the exceptionally high degree of correlation in annual balance between North Cascade glaciers (Pelto, 1997). The lowest cross-correlation value for annual balance, between any pair of the 14 glaciers observed by the North Cascades National Park Service, USGS and NCGCP is 0.79 (Pelto and Riedel, in press).

The different behavior of adjacent glacier termini based on differing topographic characteristics in the North Cascades was observed on South and North Klawatti Glaciers (Tang-
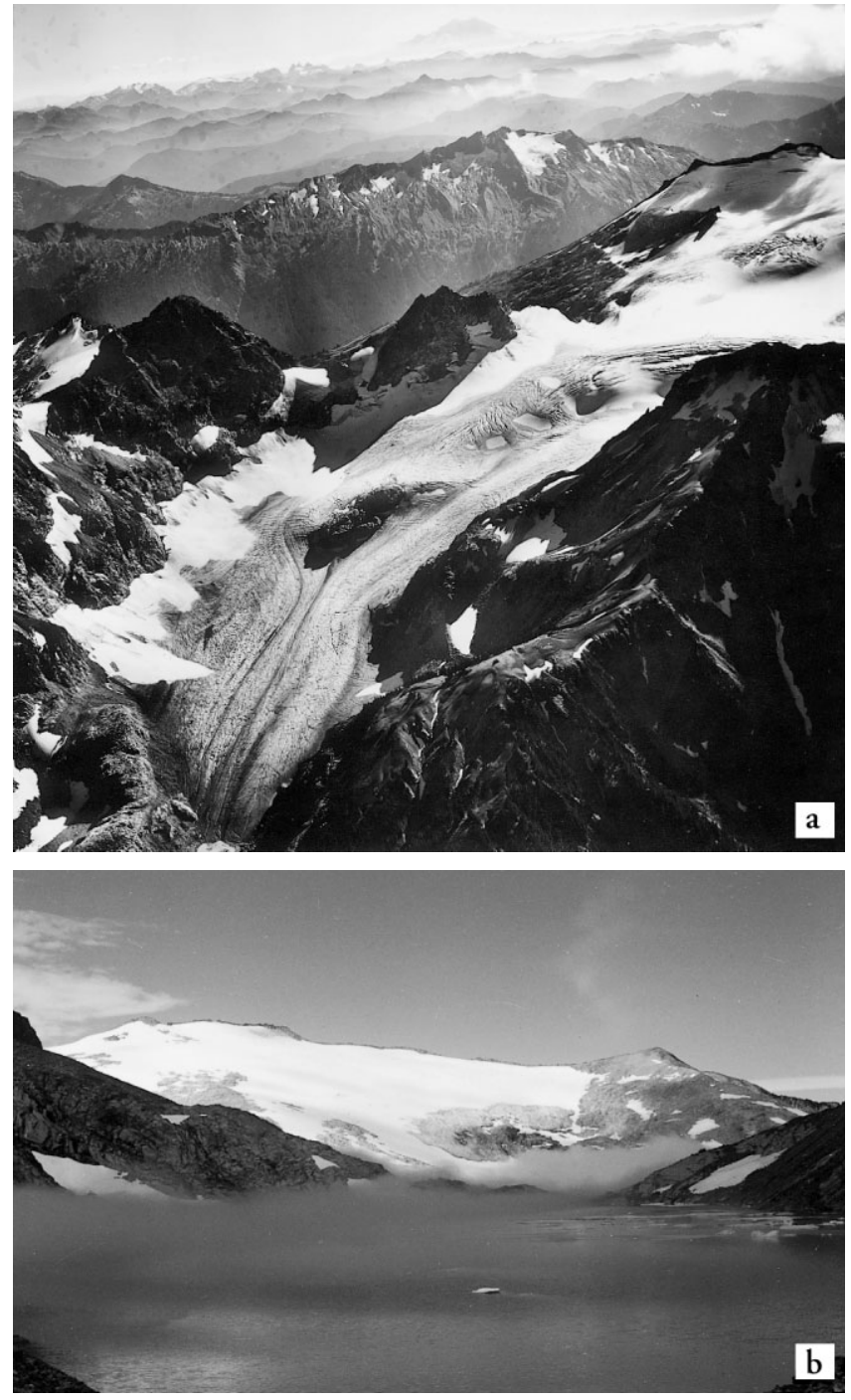

Fig. 4. (a) Honeycomb Glacier in 1967, a type 3 glacier, which has no crevassing or motion in the terminus region. This is still a large glacier, though it did retreat $480 \mathrm{~m}$ during the period 1979-97 (W. Long). (b) Foss Glacier in 1995. The low slope and lack of crevassing of this type 3 glacier is evident.

born and others, 1990). From 1947 to 1961, North Klawatti Glacier lost a volume equivalent to a mean thickness of $8.3 \mathrm{~m}$, continuing its ongoing retreat, while South Klawatti Glacier gained a thickness equivalent to a mean thickening of $5.8 \mathrm{~m}$ (Tangborn and others, 1990). North Klawatti Glacier is a type 3 glacier, and South Klawatti a type 1 glacier. The difference in the degree of crevassing alone indicates a significant difference in flow. The adjacent glaciers' differing responses fit the overall pattern for glaciers of their respective types in the North Cascades, and are not an anomalous case. We identified no important microclimatic effects that created differing mass-balance conditions on glaciers across the North Cascades (Pelto, 1996, 1997).

An even more striking example is that of Neve and Ladder Creek Glaciers, which share the same accumulation zone and have termini that both end at approximately $1680 \mathrm{~m}$. The shared accumulation zone between 2000 and $2400 \mathrm{~m}$ flows into a pass at $2000 \mathrm{~m}$, where the glacier turns both east and west. Ladder Creek Glacier flows northwest and is a type 1 glacier with a steep, shorter terminus region, $1200 \mathrm{~m}$ from pass to terminus, comparatively rapid velocity and was noted to advance by Hubley (1956). Neve Glacier is a type 2 glacier, slightly larger than Ladder Creek Glacier and with a longer terminus region, $1920 \mathrm{~m}$ from pass to 


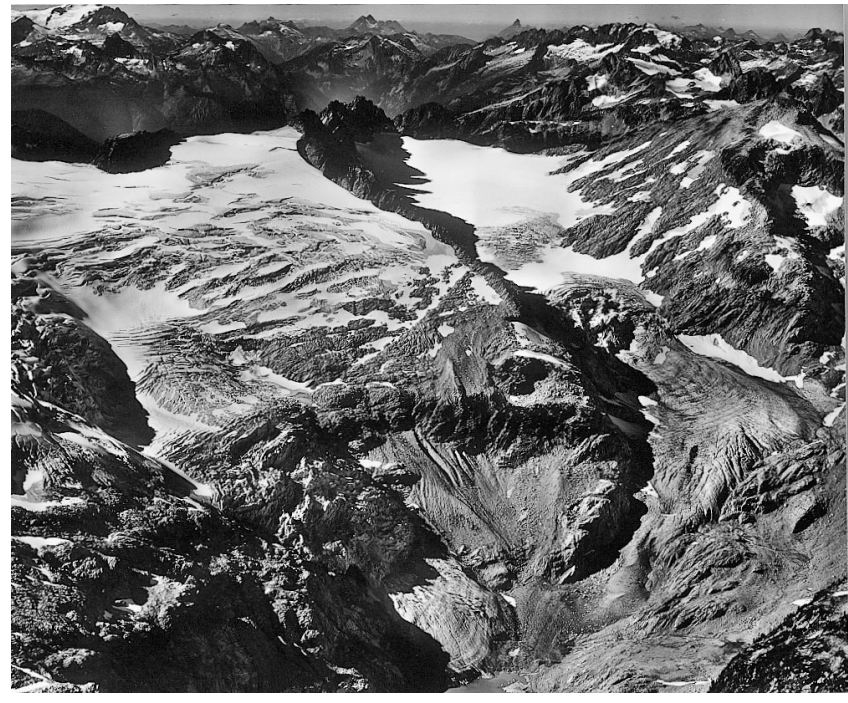

Fig. 5. North and South Klawatti Glaciers from the north. Note the difference in surface slope and crevassing of South Klawatti Glacier (left) and North Klawatti Glacier (right) (A. Post, USGS).

terminus. This results in a gentler slope and consequently slower velocity. This glacier did not advance, though crevassing did increase within $500 \mathrm{~m}$ of the terminus, slowing the retreat to a standstill.

Observation of different responses of glacier types to climate change is not unique to the North Cascades. In Switzerland a sample of 38 glaciers with 150 year long terminus records was divided into four classes, with different types of terminus response for each class (Herren and others, 1999):

(1) Large valley glaciers such as Gornergletscher which has retreated rapidly and continuously.

(2) Small mountain glaciers such as the Saleina, which advanced twice during the 20th century, though retreat was more pronounced.

(3) Large mountain glaciers, such as the Tschierva, which follow the same pattern as Saleina except with more significant retreat.

(4) Small cirque glaciers, such as Gran Plan Névé, which retreated slowly throughout the 20th century.

\section{THEORETICAL ESTIMATES OF RESPONSE TIME}

A major difficulty in the identification of $T_{\mathrm{m}}$ is that after a climate change climate conditions do not reach a new steady state for periods comparable to the $T_{\mathrm{m}}$ of glaciers. Each glacier is then adjusting to the continually changing climate conditions and never achieves a steady state, due to the non-steady climate (Schwitter and Raymond, 1993). Schwitter and Raymond (1993) noted that these difficulties are minimized with regard to changes from the LIAM to the present, because the basic climate change since the late 19th century has been from a LIA climate favorable to glaciers and a post-LIA climate unfavorable for glaciers. Changes in North Cascade terminus behavior and glacier thickness from the LIAM to the present are large compared to changes in response to more recent climate changes (Schwittter and Raymond, 1993).

The observed terminus record of North Cascade glaciers indicates a $T_{\mathrm{m}}$ range of 20-30 years on type 1 glaciers, approximately 40-60 years on type 2 glaciers and a minimum of 60-100 years on type 3 glaciers. How do these values compare to those calculated from the equations of Jóhannesson and others (1989)?

Jóhannesson and others (1989) compared two means of calculating $T_{\mathrm{m}}$ :

$$
T_{\mathrm{m}}=f L / u_{\mathrm{t}}
$$

and

$$
T_{\mathrm{m}}=h /-b_{\mathrm{t}} .
$$

$T_{\mathrm{m}}$ in these equations is potentially dependent on four variables: the glacier length, $L$, velocity of the glacier at the terminus, $u_{\mathrm{t}}$, the thickness of the glacier, $h$, and the net annual balance at the terminus, $b_{\mathrm{t}}$. Equation (1), which was pro-

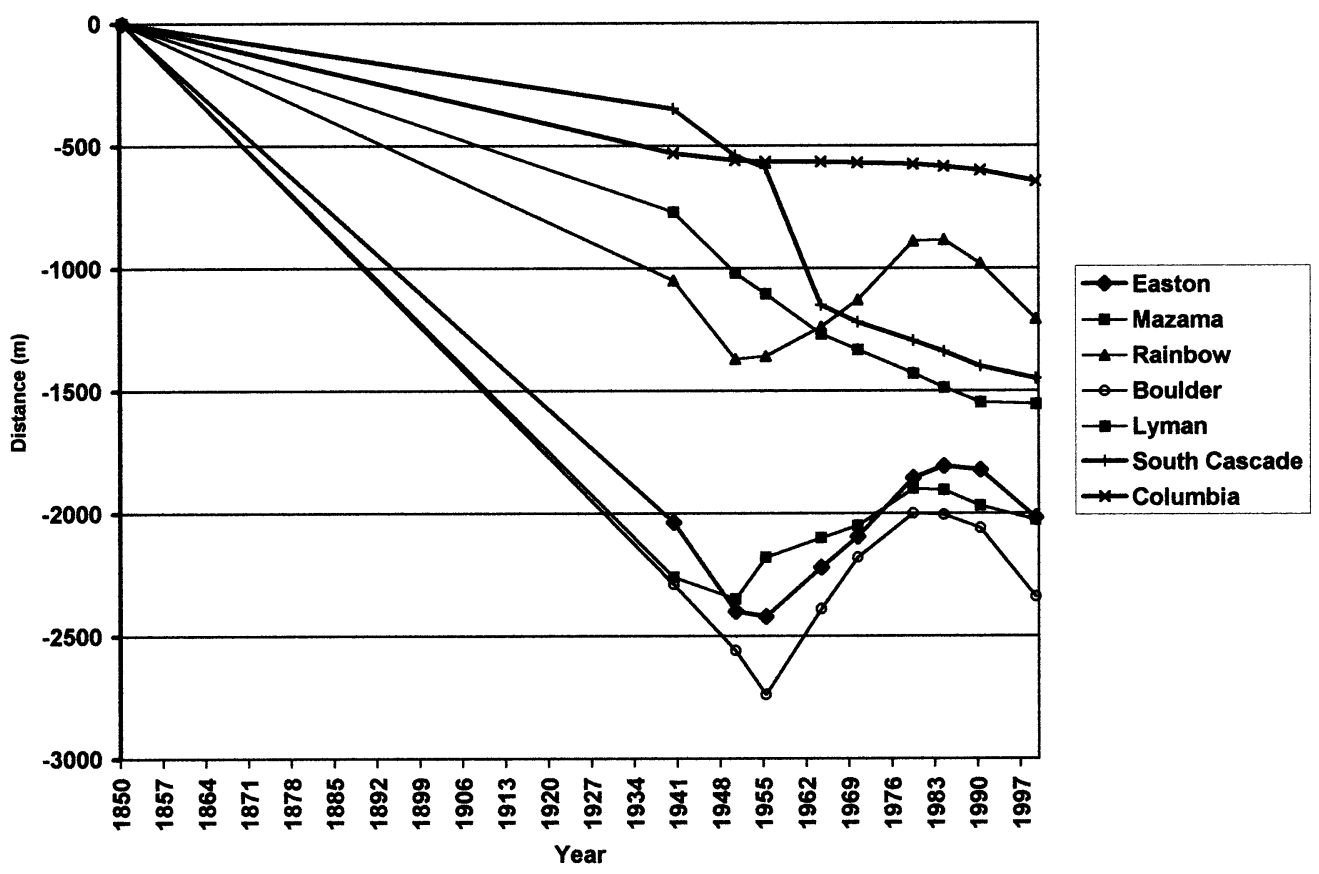

Fig. 6. Cumulative terminus-position change on seven North Cascade glaciers since approximately 1850. Easton, Mazama, Boulder and Rainbow Glaciers are type 1 glaciers and all show a period of advance. Columbia Glacier, a type 2 glacier, has a moderate but continuous retreat. Lyman and South Cascade Glaciers retreated slowly at first, but have now accelerated. 
Table 4. Variables used in Equations (1) and (2) and the calculated and observed $T_{\mathrm{m}}$

\begin{tabular}{|c|c|c|c|c|c|c|c|c|}
\hline Glacier & Type & $L$ & $u_{\mathrm{t}}$ & $h$ & $b_{\mathrm{t}}$ & $\Delta l$ & $T_{\mathrm{m}}(1)$ & $T_{\mathrm{m}}(2)$ \\
\hline Colonial & 3 & 1500 & 0.003 & 50 & -4.5 & -310 & 167 & 11 \\
\hline Columbia & 2 & 1600 & 0.004 & 100 & -4.5 & -610 & 133 & 22 \\
\hline Daniels & 2 & 800 & 0.009 & 50 & -4 & -960 & 30 & 12 \\
\hline Easton & 1 & 4000 & 0.024 & 75 & -6.5 & -2420 & 55 & 11 \\
\hline Foss & 3 & 1000 & 0.004 & 50 & -4.5 & -1060 & 83 & 16 \\
\hline Honeycomb & 3 & 4400 & 0.006 & 100 & -6 & -2360 & 244 & 12 \\
\hline Ice Worm & 2 & 500 & 0.002 & 50 & -4 & -930 & 83 & 16 \\
\hline Kennedy & 1 & 2400 & 0.020 & 100 & -6 & -0.006 & 40 & 16 \\
\hline Ladder Creek & 1 & 2600 & 0.025 & 100 & -5 & -1230 & 35 & 20 \\
\hline Lewis & 3 & 300 & 0.001 & 50 & -2 & -280 & 100 & 12 \\
\hline Lower Curtis & 1 & 1800 & 0.020 & 100 & -5.5 & -540 & 30 & 18 \\
\hline Lyman & 3 & 600 & 0.005 & 50 & -5 & -1430 & 40 & 10 \\
\hline Lynch & 2 & 1200 & 0.010 & 100 & -4 & -450 & 33 & 25 \\
\hline Neve & 2 & 3500 & 0.008 & 100 & -4.5 & -800 & 146 & 22 \\
\hline Rainbow & 1 & 2700 & 0.018 & 100 & -5 & -1370 & 60 & 20 \\
\hline South Cascade & 3 & 3100 & 0.008 & 80 & -6 & -1500 & 129 & 13 \\
\hline Yawning & 2 & 800 & 0.005 & 50 & -4 & -310 & 53 & 12 \\
\hline
\end{tabular}

Notes: $L$, glacier length $(\mathrm{m}) ; u_{\mathrm{t}}$, terminus-region velocity $\left(\mathrm{m} \mathrm{a}^{-1}\right) ; h$, ice thickness $(\mathrm{m})$ near terminus; $b_{\mathrm{t}}$, annual balance $\left(\mathrm{m} \mathrm{a}^{-1}\right)$ in the terminus region; $\Delta l$, change in glacier length $(\mathrm{m})$ since LIA maximum; $T_{\mathrm{m}}(1), T_{\mathrm{m}}$ from Equation (1) with $f=0.3 ; T_{\mathrm{m}}(2), T_{\mathrm{m}}$ from Equation (2).

posed by Nye (1960), produces longer response times of 1001000 years, and Equation (2) response times of $10-100$ years (Jóhannesson and others, 1989). The variable $f$ is a shape factor that is the ratio between changes in thickness at the terminus and changes in thickness at the glacier head (Schwitter and Raymond, 1993). Similar changes in ice thickness will yield a value of $f=1 ; f=0.5$ corresponds to a linear decrease of thickness change from a maximum at the terminus to zero at the head. The mean value of $f$ has been determined as 0.3 (Schwitter and Raymond, 1993), and this value of $f$ is applied. This equation is quite sensitive to terminus velocity, which is often spatially inconsistent.

Table 4 displays the variables used in determining $T_{\mathrm{m}}$ for 17 North Cascade glaciers, the calculated $T_{\mathrm{m}}$ from Equation (1) and $T_{\mathrm{m}}$ from Equation (2). Each variable, except $h$, has been observed on each glacier by the USGS (South Cascade Glacier) or NCGCP. Equation (2) yields values that are lower than the terminus observation-based estimates of $T_{\mathrm{m}}$ for North Cascade glaciers of types 2 and 3, but the difference is smaller for type 1 glaciers. Equation (1) overestimates $T_{\mathrm{m}}$ and, because of the wide spatial variability of $u_{\mathrm{t}}$, is not expected to yield a consistently accurate result on alpine glaciers.

South Cascade Glacier, like all type 3 glaciers, is still adjusting to post-LIA warming and the discontinuous but progressive warming of the past century. This is not unique to the North Cascades: many alpine glaciers have not yet fully adjusted to post-LIA warming. Ptarmigan and Lemon Creek Glaciers, Alaska; Gornergletscher and Rhonegletscher, Switzerland; Athabasca Glacier, Canada; and several glaciers in the Darwin Cordillera, Chile have retreated continuously during the past century (Holmund and Fuenzalida, 1995; Marcus and others, 1995; Herren and others, 1999).

\section{CONGLUSIONS}

North Cascade glaciers had a varied terminal response to the 1944 climate change, with only type 1 glaciers advancing. Based on this study, the failure of type 2 and 3 glaciers to advance is a function of their incomplete adjustment to the post-LIA progressive warming. Thus, they were still sig- nificantly out of equilibrium in 1944, after approximately a half-century of retreat (Burbank, 1981), and the modest positive mass balances did not trigger a glacier advance. Pelto $(1996,1997)$ noted the high cross-correlation in observed annual balance on North Cascade glaciers (Fig. 7). This similarity is true regardless of glacier type, and shows that microclimates are not the key to differences in behavior. Instead it is the physical characteristics slope, terminus velocity, thickness and accumulation rate of the glacier that determine its recent terminus behavior and response time. Response is thus the key to understanding the differences in terminus behavior of North Cascade glaciers during the study interval.

An example is the adjacent North Klawatti and South Klawatti Glaciers. South Klawatti advanced during the period 1950-75 and North Klawatti continued to retreat. The glaciers have different area-altitude distributions, to which Tangborn and others (1990) attributed the differential terminus response. However, the different area-altitude distribution is both a result of slower response and a reflection of the differing topographic setting.

Porter (1986) noted that many alpine glaciers experienced nearly synchronous reversals in terminus behavior around 1950. This change in glacier terminus behavior prompted Jóhannesson and others (1989) to suggest that alpine glacier behavior is dominated by short-term climate effects. In the North Cascades, this synchronous reversal to advance and later to retreat of only type 1 glaciers indicates that in the North Cascades only glaciers close to equilibrium underwent a reversal in terminus behavior due to shortterm climate effects. Glacier termini such as those of Honeycomb, Lyman, Columbia, Milk Lake and South Cascade Glaciers were only modestly affected by recent short-term climate changes in the North Cascades.

North Cascade glaciers occupy an exceptionally temperate maritime climate for glaciers. $T_{\mathrm{s}}$ on North Cascade glaciers is short (Hubley, 1956), ranging from 4 to 16 years in response to both positive and negative mass-balance changes.

$T_{\mathrm{m}}$ varies considerably even between similarly sized glaciers in this region. The key variables that decrease $T_{\mathrm{m}}$ are factors that increase mean glacier velocity, accumu- 


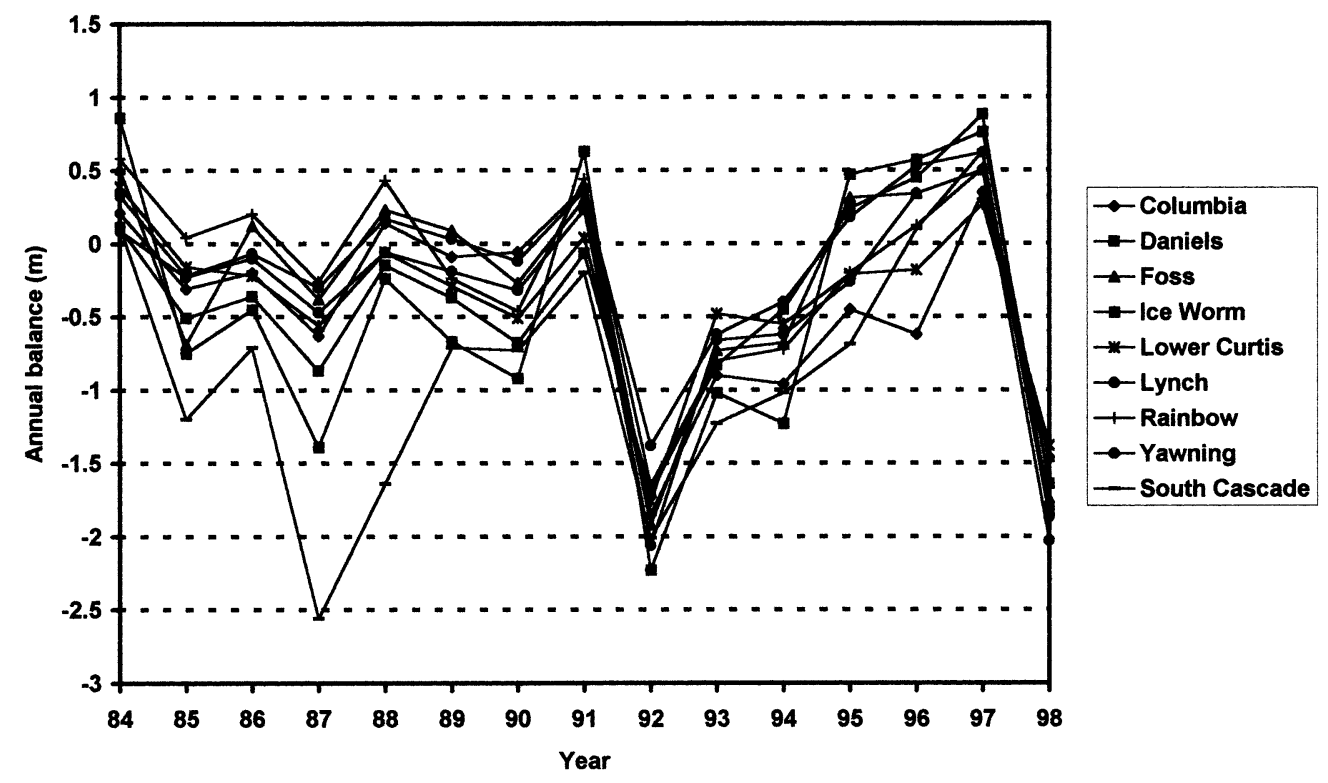

Fig. 7. Annual balance of nine North Cascade Glaciers, 1984-98, in m w.e. (Pelto, 1996; Krimmel, 1999).

lation rates and glacier slopes in particular. The response times of 30-100 years for most of these small glaciers indicate that with a substantial climate change the initial response may be rapid, but full adjustment is not rapid in the North Cascade Range.

\section{AGKNOWLEDGEMENTS}

The comments of R. LeB Hooke, M. Hoelzle, W. Haeberli, T. Jóhannesson, M. Sturm and J. G. Cogley have been most helpful. The USGS maps and photographs provided by A. Post and D. Hirst were essential to this project. The fine ongoing research initiated by M.F. Meier and currently guided by R. M. Krimmel of the USGS on South Cascade Glacier provided essential long-term data.

\section{REFERENCES}

Burbank, D.W. 1981. A chronology of late Holocene glacier fluctuations on Mt. Rainier. Arct. Alp. Res., 13(4), 369-386.

Driedger, C. L. and P. M. Kennard. 1986. Ice volumes on Cascade volcanoes: Mount Rainier, Mount Hood, Three Sisters, and Mount Shasta. U.S. Geol. Surv. Prof. Pap. 1365.

Ebbesmeyer, C. C., D. R. Cayan, D. R. McLain, F. H. Nichols, D. H. Peterson and K.T. Redmond. 1991. 1976 step in the Pacific climate: forty environmental changes between 1968-1975 and 1977-1984. In Betancourt, J. L. and V. Tharp, eds. Proceedings of the 7th Annual Pacific Climate (PACLIM) Workshop, 10-13 April 1990, Asilomar, California. Sacramento, CA, California Department of Water Resources, 129-141. (Interagency Ecological Studies Program Technical Report 26.)

Harper, J. T. 1993. Glacier terminus fluctuations on Mount Baker, Washington, U.S.A., 1940-1990, and climatic variations. Arct. Alp. Res., 25(4), 332-340.

Heikkinen, A. 1984. Dendrochronological evidence of variation of Coleman Glacier, Mt. Baker, Washington. Arct. Alp. Res., 16(1), 53-54.

Herren, E. R., M. Hoelzle and M. Maisch. 1999. The Swiss glaciers, 1995/96 and 1996/97. Zürich, Swiss Academy of Sciences. Glaciological Commission; Federal Institute of Technology. Laboratory of Hydraulics, Hydrology and Glaciology. (Glaciological Report No. 117/118.)

Holmlund, P. and H. Fuenzalida. 1995. Anomalous glacier responses to 20th century climatic changes in Darwin Cordillera, southern Chile. F. Glaciol., 41 (139), 465-473.

Hubley, R. G. 1956. Glaciers of the Washington Cascade and Olympic Mountains; their present activity and its relation to local climatic trends. F. Glaciol., 2(19), 669-674.

Jóhannesson, T., G. Raymond and E. Waddington. 1989. Time-scale for adjustment of glaciers to changes in mass balance. f. Glaciol., 35(121), 355-369.

Krimmel, R. M. 1970. Gravimetric ice thickness determination, South Cascade
Glacier, Washington. Northwest Sci., 44(3), 147-153.

Krimmel, R. M. 1994. Runoff, precipitation, mass balance, and ice velocity measurements at South Cascade Glacier, Washington, 1993 balance year. U.S. Geol. Surv. Water-Resour. Invest. Rep. 94-4139.

Krimmel, R. M. 1996. Water, ice, and meteorological measurements at South Cascade Glacier, Washington, 1995 balance year. U.S. Geol. Surv. Water-Resour. Invest. Rep. 95-4174.

Krimmel, R. M. 1999. Analysis of difference between direct and geodetic mass balance measurements at South Cascade Glacier, Washington. Geogr. Ann., 81A(4), 653-658.

Long, W. A. 1953. Recession of Easton and Deming glaciers. Sci. Mon., 76(4), 241-247.

Long, W. A. 1955. What's happening to our glaciers. Sci. Mon., 81 (2), 57-64.

Long, W. A. 1956. Present growth and advance of Boulder Glacier, Mt. Baker. Sci. Mon., 83(1), 1-2.

Marcus, M. G., F. B. Chambers, M. M. Miller and M. Lang. 1995. Recent trends in the Lemon Creek Glacier, Alaska. Phys. Geogr., 16 (2), 150-161.

Meier, M. F. and A. S. Post. 1962. Recent variations in mass net budgets of glaciers in western North America. International Association of Scientific Hydrology Publication 58 (Symposium at Obergurgl 1962 - Variations of the Regime of Existing Glaciers ), 63-77.

Miller, C. D. 1969. Chronology of Neoglacial moraines in the Dome Peak area, North Cascade Range, Washington. Arct. Alp. Res., 1(1), 49-66.

Nye, J. F. 1960. The response of glaciers and ice-sheets to seasonal and climatic changes. Proc. R. Soc. London, Ser. A, 256(1287), 559-584.

Paterson, W. S. B. 1994. The physics of glaciers. Third edition. Oxford, etc., Elsevier. Pelto, M. S. 1988. The annual balance of North Cascade glaciers, Washington, U.S.A., measured and predicted using an activity-index method. F. Glaciol., 34(117), 194-199.

Pelto, M. S. 1993. Current behavior of glaciers in the North Cascades and effect on regional water supplies. Wash. Geol., 21 (2), 3-10.

Pelto, M. S. 1996. Annual net balance of North Cascade glaciers, 1984-94. F. Glaciol., $42(140), 3-9$.

Pelto, M. S. 1997. Correspondence. Reply to comments of Meier and others on "Annual net balance of North Cascade glaciers, 1984-94" by Mauri S. Pelto. 7. Glaciol., 43(143), 193-196.

Pelto, M. S. and J. Riedel. In press. Spatial and temporal variations in annual balance of North Cascade glaciers, Washington, 1984-2000. Hydrol. Processes.

Porter, S. C. 1986. Pattern and forcing of Northern Hemisphere glacier variations during the last millennium. Quat. Res., 26(1), 27-48.

Post, A., D. Richardson, W.V. Tangborn and F. L. Rosselot. 1971. Inventory of glaciers in the North Cascades, Washington. U.S. Geol. Surv. Prof. Pap. 705-A.

Rusk, C. E. 1924. Tales of a western mountaineer. New York, Houghton Mifflin Co. Schwitter, M. P. and C. F. Raymond. 1993. Changes in the longitudinal profiles of glaciers during advance and retreat. f. Glaciol., 39(133), 582-590.

Tangborn, W. 1980. Two models for estimating climate-glacier relationships in the North Cascades, Washington, U.S.A. F. Glaciol., 25(91), 3-21.

Tangborn, W. V., A. G. Fountain and W. G. Sikonia. 1990. Effect of area distribution with altitude on glacier mass balance - a comparison on North and South Klawatti glaciers, Washington State, U.S.A. Ann. Glaciol., 14, 278-282. 